\title{
Eco-friendly cultivation of Keeled mullet (Liza carinata) in biofloc system.
}

\author{
Magdy T. Khalil ${ }^{1}$; Ragab A. R. Mohamed ${ }^{2}$; Ragaa El-Deeb ${ }^{1}$; Ashraf Suloma ${ }^{3}$; \\ Basem S. Abd-alatty ${ }^{2}$ and Shimaa A. henish ${ }^{2}$. \\ 1- Zoology Dept, Fac. Sci. Ain Shams University, Egypt. \\ 2- National Inst. of Oceanography and Fisheries (NIOF), Egypt. \\ 3- Fish Nutrition Lab (FNL), Animal Production Dept, Faculty of Agriculture, Cairo \\ University, Egypt.
}

\section{ABSTRACT}

A detailed study was carried out to evaluate the suitability of biofloc system condition for cultivation of Keeled mullet (Liza carinata) fish. The experimental design consisted of $2 \times 2$ factors experimental arrangement of two levels of crude protein (23 and 28\% CP) and two culture systems (clear water system (CWS) change and biofloc treatment (BFT) with zero water exchange): $\left(\mathrm{CWS}^{23 \%}, \mathrm{CWS}^{28 \%}, \mathrm{BFT}^{23 \%}\right.$ and $\mathrm{BFT}^{28 \%}$ ), where the superscripts refer to the levels of crude protein. Each treatment included three glass aquaria $(80 \times 45 \times 30 \mathrm{~cm})$ and stocked by 15 fry per aquarium with an average initial body weight of $0.26 \pm 0.003 \mathrm{~g}$. Total weight gain (TWG), average daily gain (ADG), and specific growth rate (SGR) were determined. Fish fed on $28 \%$ CP had significantly higher values of FBW, FI, FCR, EG and ER (24.41, 25.81, 1.06, 34.20 and 20.68, respectively) compared with values for fish fed on $23 \%$ CP (17.91, 1.19, 27.38 and 17.86, respectively). Fish fed on 23\% CP had significantly higher PER and PPV values (3.83 and 72.91, respectively). Fish reared under CWS had significantly higher FI, FCR and ER (28.36, 1.38 and 20.22, respectively), while fish reared under BFT had significantly higher PER, EG and PPV values (4.57, 31.62 and 87.40, respectively). The highest amount of feed intake was recorded by $\mathrm{CWS}^{28 \%}$ (33.94). CWS ${ }^{28 \%}$ treatment had significantly highest FBW (25.45) value, while CWS ${ }^{23 \%}$ treatment had the lowest FBW (16.40). Fish reared under biofloc treatment recorded the highest $\sum \omega_{3}$ levels in their whole bodies compared to that reared under (CWS) clear water system. It could be concluded that biofloc technology is a suitable system for Liza carinata cultivation economically and environmentally.

Keywords: Liza carinata, biofloc, cultivation, water quality, growth performance.

\section{INTRODUCTION}

World aquaculture is growing very fast to participate in solving the problem of protein food shortage especially in the developing countries. This industry causes high pressure on the environment due the great waste products in water bodies (Subasinghe, 2005; Gutierrez-Wing and Malone, 2006; Matos et al., 2006; De Schryver et al., 2008). So, there was a need to develop a technology suitable economically and environmentally (Van Wyk et al., 1999; Kuhn et al., 2010). Biofloc is one of these technologies which improve water quality as it depends on adding extra carbon source in aquaculture system causing developing of bacteria which have two main principle roles; the first causing nitrogen uptake and the second is that fish can feed on it. This improve water quality and minimize water exchange and the bacteria also participate as fed for aquatic organisms rich in protein and this cause low cost of biofloc (Avnimelech, 1999; Hargreaves, 2006; Crab et al., 2007, 2009, 2010a). Biofloc technology has been used in high intensive farming systems of several shrimp species, such as Penaeus monodon, Litopenaeus vannamei, and Macrobrachium 
rosenbergii (Burford et al., 2003; Hariet al., 2006; Crab et al., 2010b). Dempster et al. (1995) and Azim et al. (2003) reviewed that tilapias being capable of both filter feeding and detritivory are ideal candidates for Biofloc Feeding Technology (BFT). Green (2010) and Bartholomew \& Kevin (2013) demonstrated that outdoor biofloc systems can be used to produce high yields of channel catfish. Hoa et al. (2013) studied the possible use of biofloc as a feed for Artemia sp. Also Artemia nauplii had been reared in 11 cones at stocking density of 2nauplii / 1 by Toi et al. (2013). Also, El-Dahhar (2007) for striped mullet used BFT under three protein levels and three metabolic rates. Liza carinata is one of the most popular fish farmed in Egypt. Liza carinata had studied from different point of view by many authors such as El-hlafawy (2004) who studied the reproductive biology of it; Gangadhara et al., (1990) had studied the food and feeding habits of it. Blader (1997) and Pombo et al. (2005) studied the suitable environment and habitats.

To our knowledge, there is no study on Liza carinata cultivation in different rearing conditions as density, polyculure and its optimum protein level. So, the objective of this study is to evaluate the suitability of biofloc system for rearing Liza carinata under different protein levels.

\section{MATERIALS AND METHODS}

\section{Experimental design and condition}

This experiment was carried out in Fish Breeding and Production Lab at National Institute of Oceanography and Fisheries in Suez governorate. Fry of Liza carinata were obtained from El-hag Zaglol fish farm (Gulf of Suez) and transported alive in aerated tank to the laboratory. Fry were acclimated for two weeks to laboratory conditions, and fed on diet contain $23 \%$ crude protein (CP). The experimental design consisted of $2 \times 2$ factors arrangement of two levels of crude protein (23 and 28\% CP) and two culture systems; clear water system (CWS) change and biofloc treatment (BFT) with zero water exchange, as continuous: (CWS ${ }^{23 \%}$, $\mathrm{CWS}^{28 \%}, \mathrm{BFT}^{23 \%}$ and $\mathrm{BFT}^{28 \%}$ ) where the superscripts refer to the levels of crude protein. Each treatment included three glass aquaria $(80 \times 45 \times 30 \mathrm{~cm})$ and stocked by 15 fry per aquarium with average initial body weight of $0.26 \pm 0.003 \mathrm{~g}$. The aquaria were filled with water from Suez Canal. Aeration was continuously provided using an air blower to maintain oxygen level not less than $(5-6 \mathrm{mg} / \mathrm{l})$. Fry were left under natural light. Fish in each replicate aquarium were weighted every 15 day and the amount of daily diet readjusted accordingly. The experiment was extended for 136 days.

\section{Biofloc system:}

For biofloc treatments, starch was added at the same amount of feeding to maintain the $\mathrm{C} / \mathrm{N}$ ratio at 1: 10 activate heterotrophic bacteria growth (Avnimelech, 1999). Starch was completely mixed in a beaker and spread to the tank surfaces at the afternoon time. Adding carbohydrate under natural light and aeration condition are the main suitable circumstances that cause floc growth and development (Azim and Little, 2008). Fish were fed three times per day. The starch was also added daily at 14:00 hour and the aquarium with clear water; no starch was added.

\section{Diet formulation:}

The experimental diets were formed from fish meal, yellow corn, sunflower oil, starch, vitamins and minerals. The composition (\%) and chemical analysis (\% dry matter bases) of experimental diets are presented in Table (1). All experimental diets were processed by blending the dry ingredients into a homogenous mixture, then sun 
flower oil was added, then water till the mixture stick together well. A home mincer with small diameter was used to form the diet too small as possible. The diet was crumbled by hand and stocked at $20^{\circ} \mathrm{C}$ in deep freezer until use according to Bryant et al. (1980) procedure.

Table 1: Chemical composition percentage of experimental diets varying in protein sources

\begin{tabular}{|c|c|c|}
\hline Ingredients composition & Diet $23 \%$ protein & Diet $28 \%$ protein \\
\hline Fish meal & $326.9 \mathrm{~g}$ & $423.1 \mathrm{~g}$ \\
\hline Yellow corn & $673.1 \mathrm{~g}$ & $576.9 \mathrm{~g}$ \\
\hline Starch & 2 & 2 \\
\hline Sunflower oil & 9 & 9 \\
\hline *Vitamins \& minerals premix & 1 & 1 \\
\hline \multicolumn{3}{|l|}{ Chemical analysis $(\%)$} \\
\hline Dry matter (DM) & 9.06 & 5.58 \\
\hline Crude protein (CP) & 22.86 & 28.43 \\
\hline Lipid & $\mathbf{1 7 . 7 0}$ & 19.02 \\
\hline Ash & 6.56 & 9.68 \\
\hline Crude fiber (CF) & 9.06 & 5.58 \\
\hline Nitrogen free extract (NFE) & 34.76 & 31.71 \\
\hline $\begin{array}{c}* * \text { Gross energy } \\
\text { (GE)(kcal/100gDM) }\end{array}$ & 438.88 & 470.28 \\
\hline $\begin{array}{l}* * * \text { Protein/energy ratio }(\mathrm{P} / \mathrm{E}) \\
(\mathrm{mg} \mathrm{CP} / \mathrm{kcal} \text { GE) }\end{array}$ & 52.09 & 60.45 \\
\hline
\end{tabular}

*Vitamins and minerals mixture each $3 \mathrm{Kg}$ of mixture content: $12 \mathrm{~m}$.IUvit.A, 22mlU vit.D3, $10 \mathrm{~g}$ vit.E, $2 \mathrm{~g}$ vit.K, $1 \mathrm{~g}$ vit.B2, $1.5 \mathrm{~g}$ vit.B6, 10mg. vit.B12, 30g.niacin, 1000mg. Folic acid, 50mg.Biotin , $10 \mathrm{~g}$ banathonic acid , 50g Zinc ,30g.Iron , 60g. Manganese, 4g Copper , 100mg. Coblat , 100mg Selenium, 1000mg iodine.

** GE (Gross energy) (kcal / 100 g DM) $=$ CP x $5.64+$ EE x $9.44+$ NFE x 4.11 calculated according to Macdonald et al. (1973).

*** Protein/energy $(\mathrm{P} / \mathrm{E})$ ratio $=$ crude protein $\mathrm{x} 10000 /$ Digestible energy according to Garling and Wilson (1976).

\section{Water quality:}

During the experimental period water temperature, salinity, dissolved oxygen (DO) and $\mathrm{pH}$ were measured. Water samples were collected weekly for total ammonia nitrogen (TAN), nitrite nitrogen $\left(\mathrm{NO}_{2}\right)$ and nitrate nitrogen $\left(\mathrm{NO}_{3}\right)$ following the standard methods for the examination of water and wastewater (APHA.1998). Biofloc volume (FV) was determined on site using Imhoff cones weekly, registering the volume taken in by the flocs in $1000 \mathrm{ml}$ of the tank water after 30 min sedimentation (Avnimelech and Kochba, 2009)

\section{Chemical analysis:}

At the beginning and the end of each experiment a random sample of fish and feed were taken. Fish was dissected to take a piece of white muscle in closed containers and stored in the deep freezer for chemical analysis to determine the proximate composition analysis of fish and diets including dry matter (DM), for crude protein by the Kjeldahl method using a Kjeltech auto-analyzer (Model 1030, Tecator, Hoganas, Sweden) (Bligh and Dyer., 1959). Etherextracts (EE) and ash contents were also determined. The chemical composition of the whole fish body and diet was determined according to the procedure of AOAC (1995).

\section{Measurement of Growth performance:}

Fish samples were taken every 15 day to determine total body weight $(\mathrm{g})$ and total body length $(\mathrm{cm})$. Feed quantity was always readjusted according to the increase in the body weight of the fish. 
Total weight gain (TWG) (g), average daily body weight gain (ADG), specific growth rate (SGR), feed conversion ratio protein (FCR) and energy retention (ER) were determined according to Castell and Tiews (1980) as follows: TWG $=[\mathrm{FBW}-$ IBW], $\mathrm{ADG}=\mathrm{TWG} /$ time, SGR \% $=100 \mathrm{X}(\mathrm{Ln}$ FBW - Ln IBW) / (t) Where: Ln: Natural $\log$, and $t$ is the duration period, $(\mathrm{SR} \%)=($ No. of fish at the end $/$ No. of fish at start) $\mathrm{x} 100, \mathrm{FCR}=\mathrm{FI} / \mathrm{WG}, \mathrm{PER}=\mathrm{WG} / \mathrm{PI}, \mathrm{PPV}=100(\mathrm{PG} / \mathrm{PI}), \mathrm{ER}=100 \mathrm{x} \mathrm{EG} / \mathrm{EI}$ and $\mathrm{Kc}=\mathrm{W} / \mathrm{L}^{3 *} 100$

\section{Fatty acid Analysis}

For the analysis of fatty acid methyl esters, $0.1 \mathrm{~g}$ of lipid weighted into $5 \mathrm{ml}$ tube with screw cap, adding $2 \mathrm{ml}$ hexane for dissolving, then $0.2 \mathrm{ml} 2 \mathrm{~N}$ methanolic $\mathrm{KOH}$ was added. The tube was vortexes 30 second and waited for a while, up to the upper layer clarified. Clarified hexane solution was put into vials and analyzed in duplicate by gas chromatography method (GC) (Pearson et al., 1981).

\section{Gas Chromatography Condition}

In order to determine fatty acid composition, the method of Bligh and Dyer (1959) was used. A homogenized fresh sample (25g) was extracted using chloroform/ methanol/water mixture $(5 \mathrm{~V} / 10 \mathrm{~V} / 5 \mathrm{~V})$. Fats extracts were converted into fatty acid methyl esters (FAME) using acetyl chloride and then analyzed by gas-liquid chromatography HP (Hewlett Packard) 6890 GC J. Chrom. Science 16,538542(1978). A fused silica capillary column HP-5 (5\% diphenyl, 95\% dimethyl polysiloxane), $30 \mathrm{~m}, 0.32 \mathrm{~mm}$ ID, $0.25 \mu \mathrm{m}$ film thickness was employed and the temperature program was as follows: initiated for $2 \min 150^{\circ} \mathrm{C}$ then increased to $200^{\circ} \mathrm{C}$ for $10 \mathrm{~min}$ and to $250{ }^{\circ} \mathrm{C}$ for $5.0 \mathrm{~min}$; held for $9 \mathrm{~min}$ at $250^{\circ} \mathrm{C}$. The carrier gas was nitrogen at $10 \mathrm{psig}$ and detection was performed with a flame ionization detector at $250{ }^{\circ} \mathrm{C}$. A programmed temperature vaporizer injector was employed in the split mode $(50: 1)$ and was heated at $220^{\circ} \mathrm{C}$. Peaks corresponding to FAME were identified by comparing their retention times with those of standard mixtures (FAME Mix, Supelco, Inc.). Peak areas were automatically integrated. Content of each fatty acid was expressed as percentage weight of total fatty acids $(\% \mathrm{wt})$.

\section{Statistics:}

Data of the experiment were analyzed by two-way analysis of variance ANOVA. Significant differences were considered at $\mathrm{P}<0.05$. When significant differences were found, Duncan's multiple range tests was used to identify differences among experimental groups. All statistical analyses were performed using Duncan multiple range test at (P0.05) level (SPSS, 1997). Floc volume (FV) was performed according to t-test

\section{RESULTS AND DISCUSSION}

\section{Water quality:}

The results of water quality and biofloc levels are shown in Table (2). In the present study, bioflocs were promoted in the BFT tanks through addition of starch as a carbon source. FV levels increased gradually, and were kept within acceptable ranges. The formation and development of bioflocs in BFT water was linked with the direct assimilation of dissolved nitrogenous matters from diets and fish excretions by heterophic bacteria (Avninelech, 1999; Ebelinget al., 2006). It should be noted that no water was discharged into the BFT tanks during the all experimental period. The measured water quality in all experimental groups remained within acceptable ranges. 
Table 2: Water quality values of aquaria used in rearing Liza carinata under different aquaculture systems and protein levels

\begin{tabular}{|c|c|c|c|c|}
\hline \multirow{3}{*}{ Parameters } & \multicolumn{4}{|c|}{ Experimental groups } \\
\hline & \multicolumn{2}{|c|}{ CWS } & \multicolumn{2}{|c|}{ BFT } \\
\hline & $23 \% \mathrm{CP}$ & $28 \%$ CP & $23 \% \mathrm{CP}$ & $28 \% \mathrm{CP}$ \\
\hline FV & - & - & $14.22 \pm 7.46$ & $15.59 \pm 8.1$ \\
\hline Salinity (g/L) & $37.83 \pm 2.3$ & $37.81 \pm 2.3$ & $37.76 \pm 2.2$ & $37.3 \pm 2.3$ \\
\hline Temperature $\left({ }^{\circ} \mathrm{C}\right)$ & $27.7 \pm 1.5$ & $27.6 \pm 1.4$ & $27.2 \pm 1.5$ & $27.2 \pm 1.5$ \\
\hline $\mathrm{DO}(\mathrm{mg} / \mathrm{L})$ & $5.16 \pm 0.75$ & $5.11 \pm 0.89$ & $5.58 \pm 0.43$ & $5.72 \pm 0.45$ \\
\hline $\mathrm{pH}$ & $8.83 \pm 0.57$ & $8.86 \pm 0.59$ & $8.89 \pm 0.48$ & $8.93 \pm 0.65$ \\
\hline $\mathrm{NH}_{3}(\mathrm{mg} / \mathrm{L})$ & $1.07 \pm 1.16$ & $1.05 \pm 1.2$ & $0.55 \pm 1.02$ & $0.61 \pm 1.03$ \\
\hline Nitrite $(\mathrm{mg} / \mathrm{L})$ & $0.024 \pm 0.21$ & $0.022 \pm 0.23$ & $0.052 \pm 0.17$ & $0.077 \pm 0.14$ \\
\hline Nitrate $(\mathrm{mg} / \mathrm{L})$ & $0.86 \pm 0.69$ & $0.92 \pm 0.65$ & $1.1 \pm 0.62$ & $1.4 \pm 0.63$ \\
\hline
\end{tabular}

The values in the same column with different superscript letters indicate statically significant difference.

\section{Growth performance:}

Crude protein levels had significantly effect on the FBW of fish. Fish fed on $28 \% \mathrm{CP}$ was significantly having higher values of TWG, ADG, and SGR (24.15, 0.189 and 3.32, respectively) than Fish fed on $23 \%$ CP $(17.65,0.138$ and 3.09, respectively). On the other hand, SR was insignificantly different between all treatments. The interaction between BFT and CWS was significantly has an effect on FBW as it was noticed that fish reared underCWS ${ }^{28 \%}$ conditions had significantly higher FBW (25.45) compared to fish reared underBFT ${ }^{28 \%}, \mathrm{BFT}^{23 \%}$ and $\mathrm{CWS}{ }^{23 \%}$ (23.39, 19.42 and 16.40, respectively). The same trend was recorded for TWG and ADG, while SGR was not affected with aquaculture system change and significantly affected by change in protein level (Table 3). This result disagrees with $\mathrm{Xu}$ et al. (2012) who recorded that the final weight, weight gain and SGR of L. vannamei in the biofloc treatments fed on diets with $30 \%$ and $35 \% \mathrm{CP}$ were significantly higher than those obtained in the control fed on the diet with $25 \% \mathrm{CP}$ and there were no significant difference among the $\mathrm{BFT}^{25 \%}, \mathrm{BFT}^{30 \%}$ and $\mathrm{BFT}^{35 \%}$.

Table 3: Growth performance and survival rate of Liza carinata reared under different aquaculture systems sand protein levels

\begin{tabular}{|c|c|c|c|c|c|c|c|}
\hline \multicolumn{2}{|c|}{ System $\quad$ Parameter } & IBW & FBW & TWG & ADG & SGR & SR \\
\hline \multirow{2}{*}{$\begin{array}{l}\text { aquacultur } \\
\text { e system }\end{array}$} & CWS & $0.26 \pm 0.02$ & $20.92 \pm 5.02^{\mathrm{a}}$ & $20.66 \pm 5.02^{\mathrm{a}}$ & $0.161 \pm 0.039^{\mathrm{a}}$ & $3.23 \pm 0.016^{\mathrm{a}}$ & $99.17 \pm 0.98^{\mathrm{a}}$ \\
\hline & BFT & $0.26 \pm 0.02$ & $21.40 \pm 2.31^{\mathrm{a}}$ & $21.13 \pm 2.30^{\mathrm{a}}$ & $0.165 \pm 0.018^{\mathrm{a}}$ & $3.24 \pm 0.061^{\mathrm{a}}$ & $99.59 \pm 0.54^{\mathrm{a}}$ \\
\hline \multirow{2}{*}{$\begin{array}{c}\text { Protein } \\
\text { levels }\end{array}$} & $23 \%$ & $0.258 \pm 0.02$ & $17.91 \pm 1.79^{b}$ & $17.65 \pm 1.79^{b}$ & $0.138 \pm 0.013^{b}$ & $3.09 \pm 0.042^{\mathrm{a}}$ & $99.67 \pm 0.57^{\mathrm{a}}$ \\
\hline & $28 \%$ & 0.268 & $24.41 \pm 1.44^{\mathrm{a}}$ & $24.15 \pm 1.43^{\mathrm{a}}$ & $0.189 \pm 0.011^{\mathrm{a}}$ & $3.32 \pm 0.071^{\mathrm{b}}$ & $99.33 \pm 0.57^{\mathrm{a}}$ \\
\hline \multirow{4}{*}{ interaction } & $\mathrm{CWS}^{23 \%}$ & $0.257 \pm 0.002$ & $16.40 \pm 1.08^{\mathrm{c}}$ & $16.14 \pm 1.08^{c}$ & $0.126 \pm 0.006^{\mathrm{c}}$ & $3.02 \pm 0.036^{\mathrm{c}}$ & $99.68 \pm 0.78^{a}$ \\
\hline & $\mathrm{CWS}^{28 \%}$ & $0.27 \pm 0.002$ & $25.45 \pm 0.69^{\mathrm{a}}$ & $25.18 \pm 0.68^{\mathrm{a}}$ & $0.197 \pm 0.006^{\mathrm{a}}$ & $3.34 \pm 0.012^{\mathrm{a}}$ & $99.33 \pm 0.81^{\mathrm{a}}$ \\
\hline & $\mathrm{BFT}^{23 \%}$ & $0.26 \pm 0.002$ & $19.42 \pm 0.19^{b}$ & $19.16 \pm 0.19^{b}$ & $0.15 \pm 0.0001^{\mathrm{b}}$ & $3.14 \pm 0.006^{\mathrm{a}}$ & $99.33 \pm 0.81^{\mathrm{a}}$ \\
\hline & $\mathrm{BFT}^{28 \%}$ & $0.267 \pm 0.002$ & $23.39 \pm 0.1 .21^{\mathrm{a}}$ & $23.11 \pm 1.22^{\mathrm{a}}$ & $0.18 \pm 0.01^{\mathrm{a}}$ & $3.27 \pm 0.042^{\mathrm{a}}$ & $99.00 \pm 1.00^{\mathrm{a}}$ \\
\hline
\end{tabular}

The values in the same column with different superscript letters indicate statically significant

difference.

Wasielesky et al. (2006) demonstrated that L. vannamei juveniles grown in a BFT had higher growth rate than that grown in CWS. Likewise, Arnold et al. (2009) found that using biofloc in a high intensity tank system with zero exchange water could significantly enhance the growth of Penaeus monodon juveniles. In the same context, Megahed (2010) reported that Penaeus semisulcatus fed on dietary protein $16.25 \%$ with biofloc could even show better growth rate than shrimp fed on $42.95 \%$ CP without biofloc. Decamp et al. (2002) found that the growth performance of $L$. 
vannamei reared in unfiltered pond water and fed either on $25 \% \mathrm{CP}$ or $35 \% \mathrm{CP}$ showed no significant differences. Also, Hari et al. (2004) found no significant differences between the specific growth rates of $P$. monodon fed on $25 \% \mathrm{CP}$ and $40 \%$ $\mathrm{CP}$ in extensive shrimp culture system and biofloc system. Ballester et al. (2010) also demonstrated that the dietary protein content of Farfante penaeus paulensis can be reduced up to $10 \%$ (from $45 \%$ to $35 \%$ ) without affecting shrimp growth performance under biofloc system. Reduction of dietary protein levels without affecting shrimp growth has been reported by several authors and microbial proteins have been provided as an important source of protein available for shrimp in these systems (Decamp, et al., 2002; Hari et al., 2004; Ballester et al., 2010). Avnimelech \& Coworkers (1994) and Azim \& Little (2008) did not find any difference in tilapia growth when protein level in feed has been rose from $25 \%$ to $35 \%$.

\section{Survival rate:}

High survival rates of the Liza carinata in the biofloc treatments were similar to that in the control group. This proves that the culture conditions in BFT aquaria were suitable for Liza carinata culture. This is in agreement with Azim and Little (2008), who stated that tilapia survival was $100 \%$ in all treatment and control aquariums. Also, Krummenauer et al. (2011) found that survival rate ranged from 75.0 to $92.0 \%$ at stocking densities ranging from 150 to $450 \mathrm{shrimp} / \mathrm{m}^{2}$; however Suresh and Lin (1992) and Rostika (2014) recorded 93.56\% and 94\% survival in Tilapia and L. vannamei biofloc culture system respectively. In line with them, Faizullah et al. (2015) recorded that survival rate of 91.8 was recorded in the rearing of the goldfish $C$. auratus young in biofloc condition and $88.8 \%$ survival rate was recorded in the control.

\section{Feed and nutrient utilization:}

Feed intake and utilization results are presented in Table (4). Fish fed on $28 \%$ CP had significantly higher values for FI, FCR, EG and ER (25.81, 1.06, 34.20 and 20.68 respectively) compared with fish fed on $23 \%$ CP $(20.58,1.19,27.38$ and 17.86, respectively). Fish fed on $23 \% \mathrm{CP}$ had significantly higher values of PER and PPV (3.83 and72.91, respectively).

Table 4: Feed and nutrient utilization values of Liza carrinata reared under different aquaculture systems and protein levels

\begin{tabular}{|c|c|c|c|c|c|c|c|}
\hline \multirow{2}{*}{$\begin{array}{c}\text { Parametem } \\
\text { System }\end{array}$} & FI & FCR & PER & PPV & EG & ER \\
\hline $\begin{array}{c}\text { aquaculture } \\
\text { system }\end{array}$ & CWS & $28.36 \pm 6.12^{\mathrm{a}}$ & $1.38 \pm 0.072^{\mathrm{a}}$ & $2.85 \pm 0.067^{\mathrm{b}}$ & $52.43 \pm 1.7^{\mathrm{b}}$ & $29.96 \pm 5.3^{\mathrm{b}}$ & $20.22 \pm 1.48^{\mathrm{a}}$ \\
\cline { 2 - 8 } & BFT & $18.34 \pm 0.039^{\mathrm{b}}$ & $0.86 \pm 0.11^{\mathrm{b}}$ & $4.57 \pm 0.22^{\mathrm{a}}$ & $87.40 \pm 0.17^{\mathrm{a}}$ & $31.62 \pm 2.8^{\mathrm{a}}$ & $18.32 \pm 4.2^{\mathrm{b}}$ \\
\hline \multirow{2}{*}{$\begin{array}{c}\text { Protein } \\
\text { levels }\end{array}$} & $23 \%$ & $20.58 \pm 2.4^{\mathrm{b}}$ & $1.17 \pm 0.26^{\mathrm{b}}$ & $3.83 \pm 0.39^{\mathrm{a}}$ & $72.91 \pm 1.7^{\mathrm{a}}$ & $27.38 \pm 4.9^{\mathrm{b}}$ & $17.86 \pm 2.7^{\mathrm{b}}$ \\
\cline { 2 - 8 } interaction & $28 \%$ & $25.81 \pm 8.9^{\mathrm{a}}$ & $1.06 \pm 0.32^{\mathrm{a}}$ & $3.60 \pm 0.075^{\mathrm{b}}$ & $66.92 \pm 1.7^{\mathrm{b}}$ & $34.20 \pm 2.5^{\mathrm{a}}$ & $20.68 \pm 3.1^{\mathrm{a}}$ \\
\cline { 2 - 8 } & $\mathrm{CWS}^{23 \%}$ & $22.77 \pm 0.083^{\mathrm{b}}$ & $1.37 \pm 0.091^{\mathrm{a}}$ & $3.10 \pm 0.94^{\mathrm{b}}$ & $58.07 \pm 2.47^{\mathrm{b}}$ & $25.39 \pm 1.20^{\mathrm{c}}$ & $21.13 \pm 1.0^{\mathrm{a}}$ \\
\cline { 2 - 8 } & $\mathrm{CWS}^{28 \%}$ & $33.94 \pm 0.085^{\mathrm{a}}$ & $1.35 \pm 0.035^{\mathrm{a}}$ & $2.61 \pm 0.18^{\mathrm{c}}$ & $46.80 \pm 2.47^{\mathrm{c}}$ & $34.53 \pm 2.5^{\mathrm{a}}$ & $19.30 \pm 1.41^{\mathrm{b}}$ \\
\cline { 2 - 9 } & $\mathrm{BFT}^{22 \%}$ & $18.39 \pm 0.068^{\mathrm{c}}$ & $0.96 \pm 0.009^{\mathrm{b}}$ & $4.56 \pm 0.29^{\mathrm{a}}$ & $87.75 \pm 2.47^{\mathrm{a}}$ & $29.37 \pm 0.31^{\mathrm{b}}$ & $14.58 \pm 0.15^{\mathrm{c}}$ \\
\cline { 2 - 7 } & $\mathrm{BFT}^{28 \%}$ & $17.69 \pm 0.046^{\mathrm{c}}$ & $0.77 \pm 0.0341^{\mathrm{c}}$ & $4.60 \pm 0.21^{\mathrm{a}}$ & $87.04 \pm 2.47^{\mathrm{a}}$ & $33.88 \pm 2.11^{\mathrm{a}}$ & $22.06 \pm 1.38^{\mathrm{a}}$ \\
\hline
\end{tabular}

The values in the same colum with different superscript latters indicate statically significant difference.

Fish reared under CWS condition had significantly higher values of FI, FCR and ER (28.36, 1.38 and 20.22, respectively), while fish reared under BFT had significantly higher values for PER, EG and PPV (4.57, 31.62 and 87.40, respectively).

Two-way ANOVA showed a significant impact due to the interaction between aquaculture system and protein levels on feed intake. The highest amount of feed intake was recorded by fish reared under $\mathrm{CWS}^{28 \%}$ conditions (33.94) followed by $\mathrm{CWS}^{23 \%}, \mathrm{BFT}^{23 \%}$ and $\mathrm{BFT}^{28 \%}(22.7,18.39$ and 17.69 , respectively). 
The highest PER and PPV values were recorded in fish reared under BFT compared to fish reared under CWS. The same results reported by Xu et al. (2012) on shrimp, and they indicated that this may be due to proteinases enzymes activities in feed digestion and biofloc that was used as food protein source. Avnimelech (2006) recorded that the increase of heterotrophic biofloc and microorganisms could break down and recycle shrimp residual feeds and wastes. Hari et al. (2004) also recorded that PER of the shrimp reared under BFT was higher than shrimp reared under CWS and that agrees with our results. Burford et al. (2003) assumed that starch addition in BFT bonds activates growth of bacterial floc and algae which in turn act as secondary protein source for fish causing improve of growth parameters.

\section{Conditional factor:}

Results recorded in Table (5) showed fish fed on $28 \%$ CP had higher FBL than fish fed on $23 \%$ CP (12.8 and 11.25, respectively). Fish reared under BFT system had higher FBL than CWS system (12.55 and 11.50, respectively). The highest $\mathrm{K}_{\mathrm{C}}$ value was recorded by fish reared under $\mathrm{CWS}^{23 \%}$ (1.50) followed by fish reared under $\mathrm{CWS}^{28}, \mathrm{BFT}^{23 \%}$ and $\mathrm{BFT}^{28 \%}$ conditions $(1.24,1.07$ and 1.09 , respectively). Fish fed on $23 \% \mathrm{CP}$ had condition factor $\left(\mathrm{K}_{\mathrm{C}}\right)$ significantly higher than fish fed on $28 \% \mathrm{CP}$ (1.29 and 1.17, respectively). Fish reared under CWS condition had significantly higher $\mathrm{K}_{\mathrm{C}}$ than that of BFT (1.37 and 1.08 , respectively).

Table 5: Initial, final body length and conditional factor $\left(\mathrm{K}_{\mathrm{C}}\right)$ values of Liza carinata reared under different aquaculture systems and protein levels.

\begin{tabular}{|l|c|c|c|c|}
\hline \multirow{2}{*}{\begin{tabular}{l} 
System \\
\multirow{2}{*}{$\begin{array}{l}\text { aquaculture } \\
\text { system }\end{array}$}
\end{tabular}} & $\mathrm{CWS}$ & $2.5 \pm 0.0001$ & $11.50 \pm 1.31$ & $\mathrm{~K}_{\mathrm{C}}$ \\
\cline { 2 - 5 } & $\mathrm{BFT}$ & $2.5 \pm 0.0001$ & $12.55 \pm 0.38$ & $1.08 \pm 0.037^{\mathrm{a}}$ \\
\hline Protein levels & $23 \%$ & $2.5 \pm 0.0001$ & $11.25 \pm 1.42$ & $1.29 \pm 0.23^{\mathrm{a}}$ \\
\cline { 2 - 5 } & $28 \%$ & $2.5 \pm 0.0001$ & $12.8 \pm 0.27$ & $1.17 \pm 0.097^{\mathrm{b}}$ \\
\hline \multirow{3}{*}{ Interaction } & $\mathrm{CWS}^{23 \%}$ & $2.5 \pm 0.0001$ & $10.30 \pm 0.0001$ & $1.50 \pm 0.10^{\mathrm{a}}$ \\
\cline { 2 - 5 } & $\mathrm{CWS}^{28 \%}$ & $2.5 \pm 0.0001$ & $12.7 \pm 0.0001$ & $1.24 \pm 0.03^{\mathrm{b}}$ \\
\cline { 2 - 5 } & $\mathrm{BFT}^{23 \%}$ & $2.5 \pm 0.0001$ & $12.2 \pm 0.0001$ & $1.07 \pm 0.01^{\mathrm{c}}$ \\
\cline { 2 - 5 } & $\mathrm{BFT}^{28 \%}$ & $2.5 \pm 0.0001$ & $12.9 \pm 0.0001$ & $1.09 \pm 0.037^{\mathrm{c}}$ \\
\hline
\end{tabular}

The values in the same column with different superscript letters indicate statically significant difference.

These results disagreed with Wassef et al. (2001) who showed that mullet (Mugil cephalus) fingerlings were fed on four diets containing 10, 15, 20 and 25\% algal meal-based diets. A fifth test diet containing $40 \%$ dietary yeast enriched with vitamin $\mathrm{E}$ was further investigated for 15 weeks. They found that condition factor $(\mathrm{K}$, value) was not significantly affected by various dietary treatments. Also, Kheir et al. (1998) attributed this fluctuation in K-value to the increase of food consumption as a result of increased metabolism, minimized oxygen consumption and an increase in growth hormone.

\section{Body chemical composition:}

The whole body chemical composition is recorded in (Table 6). In the present study, fish reared under BFT system had the highest dry matter (DM) and ash content (27.81 and 15.42, respectively) compared to fish reared under CWS system (26.67 and 14.43 , respectively). The highest DM content was recorded by fish reared under $\mathrm{BFT}^{28 \%}$ conditions (28.04), followed by $\mathrm{BFT}^{22 \%}, \mathrm{CWS}^{22 \%}$ and $\mathrm{CWS}^{28 \%}(27.57,27.44$ and 25.89, respectively). Protein levels revealed significant effects on CP. Fish reared under CWS had the highest CP and EE content (68.83 and 17.21, respectively) when compared to fish reared under BFT (68.65 and 16.05, respectively). The highest EE content was recorded by fish reared under $\mathrm{CWS}^{23 \%}$ (19.79) followed by fish reared 
underBFT ${ }^{23 \%}, \mathrm{BFT}^{28 \%}$ and fish reared under $\mathrm{CWS}^{28 \%}$ (17.05, 15.43and14.65, respectively), where no significant difference were found between fish reared under CWS and fish reared under BFT on the whole body dry matter (DM) and crude protein (CP). This agreed with Azim and Little (2008) who revealed that no significant difference between clear water system (CWS) and Biofloc technology (BFT) system were recognized.

Table 6: Chemical composition values of muscle of Liza carinata reared under different aquaculture systems and protein levels.

\begin{tabular}{|l|c|c|c|c|c|}
\hline \multicolumn{2}{|l|}{ System } & DM & CP & EE & ASH \\
\hline \multirow{2}{*}{$\begin{array}{l}\text { aquaculture } \\
\text { system }\end{array}$} & CWS & $26.67 \pm 1.55^{\mathrm{b}}$ & $68.83 \pm 0.63^{\mathrm{a}}$ & $17.21 \pm 2.8^{\mathrm{a}}$ & $14.43 \pm 1.89^{\mathrm{b}}$ \\
\cline { 2 - 6 } Protein levels & $\mathrm{BFT}$ & $27.81 \pm 0.58^{\mathrm{a}}$ & $68.65 \pm 1.42^{\mathrm{a}}$ & $16.05 \pm 1.19^{\mathrm{b}}$ & $15.42 \pm 3.22^{\mathrm{a}}$ \\
\cline { 2 - 6 } & $23 \%$ & $27.51 \pm 1.13^{\mathrm{a}}$ & $69.13 \pm 0.62^{\mathrm{a}}$ & $18.42 \pm 2.63^{\mathrm{a}}$ & $12.68 \pm 2.06^{\mathrm{b}}$ \\
\cline { 2 - 6 } Interaction & $28 \%$ & $26.96 \pm 1.28^{\mathrm{b}}$ & $68.34 \pm 0.71^{\mathrm{b}}$ & $14.85 \pm 1.39^{\mathrm{b}}$ & $17.18 \pm 3.06^{\mathrm{a}}$ \\
\cline { 2 - 6 } & $\mathrm{CWS}^{23 \%}$ & $27.44 \pm 1.53^{\mathrm{b}}$ & $68.41 \pm 0.37^{\mathrm{b}}$ & $19.79 \pm 0.31^{\mathrm{a}}$ & $12.81 \pm 0.75^{\mathrm{c}}$ \\
\cline { 2 - 6 } & $\mathrm{CWS}^{28 \%}$ & $25.89 \pm 1.35^{\mathrm{c}}$ & $69.24 \pm 0.58^{\mathrm{a}}$ & $14.65 \pm 0.59^{\mathrm{c}}$ & $16.07 \pm 0.58^{\mathrm{b}}$ \\
\cline { 2 - 6 } & $\mathrm{BFT}^{23 \%}$ & $27.57 \pm 0.33^{\mathrm{b}}$ & $69.85 \pm 0.58^{\mathrm{a}}$ & $17.05 \pm 0.39^{\mathrm{b}}$ & $12.55 \pm 0.98^{\mathrm{c}}$ \\
\cline { 2 - 6 } & $\mathrm{BFT}^{28 \%}$ & $28.04 \pm 0.76^{\mathrm{a}}$ & $67.44 \pm 0.64^{\mathrm{c}}$ & $15.43 \pm 0.58^{\mathrm{c}}$ & $18.29 \pm 0.50^{\mathrm{a}}$ \\
\hline
\end{tabular}

The values in the same column with different superscript letters indicate statically significant difference.

CWS: Clear water system.

BFT: Biofloc food technology.

In the same context, no significant difference between change water system (CWS), and BFT system in shrimp dry matter and crude protein content, but biofloc showed superiority for ether extract and ash content, while a significant in biofloc composition in terms of protein and ash content between different protein levels $(\mathrm{Xu}$ and Pan, 2012).

On the other hand, the difference of DM, CP, and ASH between CWS and BFT and protein levels were significant in the present study. The same trend was observed by $\mathrm{Xu}$ et al. (2012) who noticed significantly decrease in biofloc protein content as dietary protein level decreased, while no change in lipid and ash content were reported between treatments. Azim et al. (2008) reported that there were significant differences in protein and fat composition of biofloc with the highest protein in the diet, but the opposite was recorded for ash and fiber composition.

Only slight differences were found in the carbohydrate, fat and ash compositions among shrimps grown in the control and biofloc tanks, representing that the quality of flesh was not affected by any of the culture conditions used in the study of Karakoltsidis et al. (1995), but proximate compositions in shrimps' flesh were affected by several factors such as season, species, growth stage and feed.

\section{Fatty acids:}

The highest $\sum \omega_{3}$ values were recorded in fish reared under $\mathrm{BFT}^{28 \%}$ condition, followed by $\mathrm{BFT}^{23 \%}, \mathrm{CWS}^{28 \%}$ and $\mathrm{CWS}^{23 \%}(12.38,9.80,5.96$ and 4.99 , respectively) (Table 7), and the highest $\sum \omega_{6}$ values were recorded in fish reared under $\mathrm{BFT}^{28 \%}$, followed by $\mathrm{BFT}^{23 \%}, \mathrm{CWS}^{28 \%}$ and $\mathrm{CWS}^{23 \%}(3.84,3.562 .64$, and 2.49 , respectively) (Table 7), which give an advantage as producing functional food, forming simple and eco-friendlily system. The $\sum \omega_{3}$ valueswere lower than that of O"zogul et al. (2009) who found it ranged from $12.66 \%$ for annular sea bream to $36.54 \%$ for European hake, whereas $\sum \omega_{6}$ value was $1.24 \%$ for Oceanic puffer and $12.7 \%$ for Flathead mullet. These values were different than that of our study as this difference in values may be attributed to the variation in species and areas of fish under study. 
In the present study, the highest average $\sum \omega_{3} / \sum \omega_{6}$ ratio was recorded in fish reared under $\mathrm{BFT}^{28 \%}$, followed by $\mathrm{BFT}^{23 \%}, \mathrm{CWS}^{28 \%}$ and $\mathrm{CWS}^{23 \%}(3.22,2.75,2.26$ and 2.00 , respectively) (Table 7 ). The $\sum \omega_{3} / \sum \omega_{6}$ ratio increased within the same treatment by increasing protein level and it was higher in BFT than CWS. These values were lower than 4.0, so they have useful effect on human health and higher than that recorded by HMSO UK(1994), who found the highest ratio was recorded in striped sea bream (1.63), followed by the wide-eyed flounder (1.45), the sand sole (1.34), while the lowest values were recorded in golden grey mullet and African tread fishes (0.51).

Table 7: Fatty acid composition in Liza carinata muscles affected by different treatments.

\begin{tabular}{|c|c|c|c|c|c|}
\hline \multirow{2}{*}{ Nature } & \multirow{2}{*}{ Fatty acid } & \multicolumn{2}{|c|}{ CWS } & \multicolumn{2}{|c|}{ Biofloc } \\
\hline & & $23 \% \mathrm{CP}$ & $28 \% \mathrm{CP}$ & $23 \% \mathrm{CP}$ & $28 \% \mathrm{CP}$ \\
\hline \multirow{13}{*}{ SFA } & C6:0 & & 0.183 & 1.719 & \\
\hline & C8:0 & 0.031 & 0.093 & & 0.070 \\
\hline & C10:0 & 0.012 & 0.053 & & 0.026 \\
\hline & C11:0 & & & & 0.132 \\
\hline & C12:0 & 0.256 & 0.198 & 0.066 & 0.223 \\
\hline & C13:0 & 1.058 & 0.545 & 0.18 & 0.162 \\
\hline & C14:0 & 4.854 & 0.274 & 5.65 & 12.07 \\
\hline & C15:0 & 5.41 & 0.089 & 4.959 & 9.12 \\
\hline & C16:0 & 38.55 & 31.06 & 39.66 & 16.01 \\
\hline & $\mathrm{C} 17: 0$ & & 11.59 & 7.82 & \\
\hline & C18:0 & 13.91 & 25.46 & 9.15 & 16.1 \\
\hline & C20:0 & 5.31 & 1.64 & 1.05 & \\
\hline & C21:0 & & & & \\
\hline \multirow{5}{*}{ MUFA } & C14:1 & 0.478 & & 0.051 & 0.323 \\
\hline & C15:1 & 0.868 & & 0.17 & 0.903 \\
\hline & C16:1 & 6.58 & 7.789 & 6.064 & \\
\hline & $\mathrm{C} 17: 1$ & 6.478 & 7.789 & & 15.23 \\
\hline & C18:1n1\&9 & 8.719 & 10.2 & 10.30 & 11.69 \\
\hline \multirow{6}{*}{ PUFA } & $\mathrm{C} 18: 3$ & & & & \\
\hline & C18: 2n 6(LA) & 1.856 & 1.247 & 0.547 & 2.045 \\
\hline & C20: 4n 6(ARA) & 1.993 & 4.088 & 4.973 & 6.637 \\
\hline & C20: 5n3 (EPA) & 2.188 & 1.394 & 1.017 & 1.804 \\
\hline & C22: 6n3 (DHA) & 1.45 & 1.873 & 4.831 & 5.749 \\
\hline & $\mathrm{C} 22: 2$ & & 1.411 & & 1.91 \\
\hline \multicolumn{2}{|l|}{$\omega_{3}$} & 4.993 & 5.961 & 9.804 & 12.386 \\
\hline \multicolumn{2}{|l|}{$\omega_{6}$} & 2.494 & 2.641 & 3.564 & 3.849 \\
\hline \multicolumn{2}{|l|}{$\omega_{3} / \omega_{6}$} & 2.000 & 2.26 & 2.75 & 3.22 \\
\hline \multicolumn{2}{|l|}{$\sum$ SFA } & 69.39 & 71.19 & 70.25 & 53.91 \\
\hline \multicolumn{2}{|l|}{$\sum$ MUSFA } & 23.12 & 17.99 & 16.58 & 28.15 \\
\hline \multicolumn{2}{|c|}{$\sum$ PUSFA } & 7.49 & 10.01 & 13.37 & 18.15 \\
\hline \multicolumn{2}{|c|}{ PUSFA/SFA } & 0.108 & 0.141 & 0.190 & 0.337 \\
\hline
\end{tabular}

The recommended minimum value of $\sum \omega_{3} / \sum \omega_{6}$ ratio is 0.45 (HMSOUK, 1994) and this agrees with UK department and also the maximum recommended value in the diet should be 4.0; this value is very useful for health as it promote cardiovascular disease, atherosclerosis and many chronic diseases reported by HMSO UK (1994); Simpolous. (2009); Polak-Juszczak and Komar-Szymczak (2009).

\section{CONCLUSION}

In conclusion, using biofloc system in aquaculture decreases the negative impact of fish farms on the environment and also improves the economic efficiency. Biofloc system is suitable for Liza carinata culture, and the obtained fish is healthy as the $\sum \omega_{3} / \sum \omega_{6}$ ratio within the recommended UK values. 


\section{REFERENCES}

American Public Health Association. Water Environment Federation (APHA) (1998). Standard Methods for the Examination of Waters and Wastewaters.

AOAC, (1995). Official Methods of Analysis, $15^{\text {th }}$ ed. Association of Official Analytical Chemists, Arlington, VA.

Arnold, S. J.; Coman, F. E.; Jackson, C. J. and Groves, S. A. (2009). High-intensity, zero water exchange production of juvenile tiger shrimp, Penaeusmonodon'. An evaluation of artificial substrates and stocking density. Aquaculture, 293: 42-18.

Avnimelech, Y. (2006). Bio-filters: the need for an new comprehensive approach. Aquaculture, 34 (3): 172-178.

Avnimelech, Y. and Kochba, M. (2009). Evaluation of nitrogen uptake and excretion by tilapia in bio floe tanks, using N15 tracing. Aquaculture, 287:163-168.

Avnimelech, Y.(1999). Carbon/nitrogen ratio as a control element in aquaculture systems. Aquaculture, 176: 227-235.

Avnimelech, Y.; Kochva, M. and Diab, S. (1994). Development of controlled intensive aquaculture systems with a limited water exchange and adjusted carbon to nitrogen ratio. Israeli Journal of Aquaculture-Bamidgeh, 46(3): 119-131.

Azim, M.E. and Little D.C. (2008). The biofloc technology (BFT) in indoor tanks: Water quality, biofloc composition, and growth and welfare of Nile tilapia (Oreochromis niloticus) Aquaculture, 283: 29-35.

Azim, M. E.; Little, D. C. and Bron, J. E. (2008). Microbial protein production in activated suspension tanks manipulating $\mathrm{C}$ : $\mathrm{N}$ ratio in feed and the implications for fish culture. Bio resource Technology, 99: 3590-3599.

Azim-, M. E.; Verdegem, M. C. J.; Mantingh, L; van Dam, A. A. and Beveridge, M. C. M. (2003). Ingestion and utilization of periphyton grown on artificial substrates by Nile tilapia (Oreochromis niloticus) Aquacult. Res., 34:85-92.

Ballester, E. L. C.; Abreu, P. C.; Cavalli, R. O.; Emerenciano, M.; Abreu, L. and Wasielesky, W. (2010). Effect of practical diets with different protein levels on the performance of Farfante penaeus paulensis juveniles nursed in a zero exchange suspended microbial floes intensive system. Aquaculture Nutrition, 16: 163-172.

Bartholomew, G. and Kevin K. S. (2013). Effect of initial biomass on Channel Catfish yield and water quality in a biofloc technology Production System. World Aquaculture Society Meetings. Saturday, February 23.

Blaber, S. J. M. (1997). Fish and fisheries of tropical estuaries. Chapman and Hall, London.

Bligh, E. G., and Dyer, W. J. (1959). A rapid method of total lipid extraction and purification. Canadian journal of biochemistry and physiology, 37(8): 911-917.

Bryant, P.; Jauncey, K. and Atack, T. (1980). Backyard fish farming. Prism press, 170 $\mathrm{pp}$.

Burford, M.A.; Thompson, P.J.; Mclntosh, R.P.; Bauman, R.H. and Pearson, D.C. (2003). Nutrient and microbial dynamics in high-intensity, zero-exchange shrimp ponds in Belize. Aquaculture, 219:393-11.Cambridge, NY, USA, 388pp.

Castell, J. D. and Tiewes, K. (1980): Report of the EIFAC, IUNS and ICES Working Group on Standardization of Methodology in Fish Research, Hamburg, FRG, 2123 March 1979. IFAC Tech. Pap. (3) 24.

Crab, R.; Avnimelech, Y.; Defoirdt, T.; Bossier, P. and Verstraete, W. (2007). Nitrogen removal techniques in aquaculture for a sustainable production. Aquaculture 270: $1-14$. 
Crab, R.; Chielens, B.; Wille, M.; Bossier, P. and Verstraete, W. (2010a). The effect of different carbon sources on the nutritional value of bioflocs, a feed for Macrobrachium rosenbergii postlarvae. Aquaculture Research, 41: 559-567.

Crab, R.; Chielens, B.;Wille, M.; Bossier, P. and Verstraete, W. (2010b). The effect of different carbon sources on the nutritional value of bioflocs, a feed for Macrobrachium rosenbergii post larvae. Aquaculture Research, 41: 559-567.

Crab, R.; Kochva, M.; Verstraete, W. and Avnimelech, Y. (2009). Bio-flocs technology application in over-wintering of tilapia. Aquaculture Engineering, 40: 105-112.

De Schryver, P.; Crab, R.; Defoirdt, T.; Boon, N. and Verstraete, W. (2008). The basics of bio-flocs technology: The added value for aquaculture. Aquaculture, 277:125137.

Decamp, O.; Conuest, L.; Forster, I. and Tacon, A. G.J. (2002). The nutrition and feeding of marine shrimp within zero-water exchange aquaculture production system: role of Eukaryotic microorganisms. In: Lee, C,S., O'Bryen, P. (Eds.), Microbial Approaches to Aquatic Nutrition within Environmentally Sound Aquaculture Production systems. World Aquqculture Society, Baton Rouge, USA, pp. 79-86.

Dempster, P.; Baird, D. J. and Beveridge, M.C.M. (1995). Can fish survive by filterfeeding on mi crop articles? Energy balance in tilapia grazing on algal suspension. Journal of Fish Biology, 47: 7-17.

Ebeling, J. M.; Timmons, M. B. and Bisogni, J. J. (2006). Engineering analysis of the stoichiometry of photo autotrophic, autotrophic, and heterotrophic removal of ammonia-nitrogen in aquaculture systems. Aquaculture, 257: 346-358.

El-Dahhar, A. A. (2007).Review Article on Protein and Energy Requirements of Tilapia and Mullet. Journal of the Arabian Aquaculture Society. 2(1): (28).

EL-Halfawy, M. M. (2004). Reproductive biology of the Mugil seheli (Family muglidae) reared in fish farm lake, Suez Canal. Egypt. J. Aquat. Res. 30(B): 234-240.

Faizullah, M.; Rajagopalsamy, C. B. T.; Ahilan, B. and Francis, T. (2015). Impact of Biofloc Technology on the Growth of Goldfish Young Ones. Indian J. Sci. Technology, 8(12).

Gangadhara, G.;Shanbhogue, S. and Gowda, H.(1990). Studies on the food and feeding habits of the grey mullet, Valamugil seheli (Forskal) from Mangalore (India) waters. Mysore J. Agric. Sci., 23 (3): 406- 410.

Green, B.W. (2010). Effect of channel catfish stocking rate on yield and water quality

Gutierrez-Wing, M.T.; Malone, R. F. (2006). Biological filters in aquaculture: trends and research directions for freshwater and marine applications. Aquac. Eng., 34 (3): 163-171.

Hargreaves, J.A. (2006). Photosynthetic suspended-growth systems in aquaculture. Aquaculture Engineering, 34: 344-363.

Hari, B.; Kurup, B.M.; Varghese, J.T.; Schrama, J.W. and Verdegem, M.C.J. (2006). The effect of carbohydrate addition on water quality and the nitrogen budget in extensive shrimp culture systems. Aquaculture, 252 (2-4): 248-263.

Hari, B.; Madhusoodana, K.; Varghese, J.T.; Schrama, J.W. and Verdegem, M. C. J. (2004). Effects of carbohydrate addition on production in extensive shrimp culture systems. Aquaculture, 241: 179-194.

HMSO UK. (1994). Nutritional aspects of cardiovascular disease. Report on health and social subjects no.46. London: HMSO.

Hoa, N.V.; Dieu, D. K.; Anh, N. T. and Van, N. T. (2013). Use of bioflocs grown at different salinities as a feed for Artemia in laboratory conditions. World Aquaculture Society Meetings. Saturday, February 23, in an intensive, mixed suspended-growth production system. N. Am. J. Aquacult., 72: 97-106. 
Kheir, M. T.; Mechail, M. M. and Abo-Hegab, S. (1998). Some biochemical changes in Oreochromis niloticus reared at different saline concentration. Egypt Journal. Zool, 30:107-129.

Krummenauer, D.; Peixoto, S.; Cavalli, R. O.; Poersch, L. H. and Wasielesky, W. (2011). Super intensive culture of white shrimp, Litopenaeus vannamei, in a biofloc technology system in southern Brazil at different stocking densities. Journal of the World Aquaculture Society, 42:726-733.

Kuhn, D. D.; Lawrence, A. L.; Boardman, G. D.; Patnaik, S.; Marsh, L. and Flick, J. G. J. (2010). Evaluation of two types of bioflocs derived from biological treatment of fish effluent as feed ingredients for Pacific white shrimp, Litopenaeus vannamei. Aquaculture, 303: 28-33

Matos, J.; Costa, S.; Rodrigues, A.; Pereira, R. and Pinto, I. S. (2006). Experimental integrated aquaculture of fish and red seaweeds in Northern Portugal. Aquaculture, 252(1): 31-42.

Megahed, M.E. (2010). The effect of microbial bioiloc on water quality, survival and growth of the green tiger shrimp (Penaeus Semisulcatus) fed with different crude protein levels. Journal of the Arabian Aquaculture Society, 5: 119-142.

Özogul, Y.; Özogul, F. H.; Çi çek, E.; Polat, A. and Kuley, E. (2009). Fat content and fatty acid compositions of 34 marine water fish species from the Mediterranean Sea. International journal of food sciences and nutrition, 60(6): 464-475.

Pearson, D.; Harold, E.; Ronald, S.K. and Ronald, S. (1981). Pearson's Chemical Analysis of Foods Book, Eighth Edition.

Polak-Juszczak, L. and Komar-Szymczak, K. (2009). Fatty acid profiles and fat contents of commercially important fish from Vistula Lagoon. Polish J. Food and Nutrition Sci., 59(3): 225-229.

Pombo, L.; Elliott, M. and Rebelo, J. E. (2005). Environmental influences on fish assemblage distribution of an estuarine coastal lagoon, Ria de Aveiro (Portugal). Sci. Mar., 69: 143-159.

Rostika, R. (2014). The reduction feed on shrimp vaname (Litopenaues vannamae) replaced by the addition biofloc in Ciamis District. Res J Biotech, 9(2):56-9.

SPSS (1997). Statistical package for the social sciences, Versions16, SPSS in Ch, ChiUSA.

Subasinghe, R. P. (2005). Epidemiological approach to aquatic animal health management: opportunities and challenges for developing countries to increase aquatic production through aquaculture. Preventive Veterinary Medicine, 67(2): $117-124$

Suresh, A.V. and Lin, C. K. (1992). Effect of stocking density on water quality and production of red tilapia in a recalculated water system. Aquaculture Engineering, 11: $1-22$.

Toi, H.T.; Ahyani, N.; Sorgeloos, P.; Bossier, P. and Van, G. (2013). Manipulation of $\mathrm{C} / \mathrm{N}$ ratio to stimulate the growth of bacteria as food for filter feeders in a laboratory culture system: a demonstration on Artemia. World Aquaculture Society Meetings. Saturday, February 23.

Van Wyk, P.; Davis-Hodgkins, M.; Laramore, C.R.; Main, K.; Mountain, J. and Scarpa, J. (1999). Farming Marine Shrimp in Recirculating Freshwater Production Systems: A Practical Manual. FDACS Contract 4520. Florida Department of Agriculture Consumer Services, Tallahassee, Florida, US.

Wasielesky, W.; Atwood, H.; Stokes, A. and Browdy, C.L. (2006). Effect of natural production in a zero exchange suspended microbial floe based super-intensive culture system for white shrimp Litopenaeus vannamei. Aquaculture, 258: 396-403. 
Wassef, E. A.; El Masry, M. H. and Mikhail1, F. R. (2001).Growth enhancement and muscle structure of striped mullet, Mugil cephalus L., fingerlings by feeding algal meal-based diets. Aquaculture Research, 32 (Suppl. 1): 315-322.

Xu, W. J.; Pan, L. Q.; Zhao, D. H.; and Huang, J. (2012). Preliminary investigation into the contribution of bioflocs on protein nutrition of Litopenaeus vannamei fed with different dietary protein levels in zero-water exchange culture tanks. Aquaculture, 350: $147-153$.

$\mathrm{Xu}$, W. J. and Pan, L.Q. (2012). Effects of bioflocs on growth performance, digestive enzyme activity and body composition of juvenile Litopenaeus vannamei in zerowater exchange tanks manipulating $\mathrm{C} / \mathrm{N}$ ratio in feed. Aquaculture, 356-357:147152.

Zaki, M. I. and El Gharabawy, M. M. (1991). Reproductive biology of Mugil capito in Egypt. Assiut Veterinary Medical Journal.

\footnotetext{
ARABIC SUMMARY

استزراع سمكه السهليه باستخدام نظام البيوفلوك الصديق للبيئه

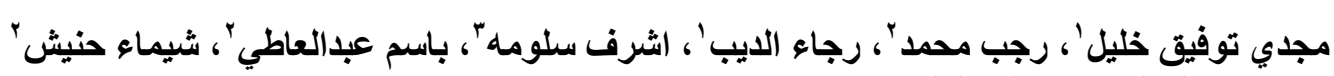

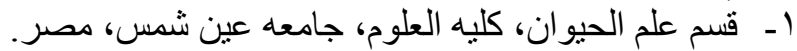

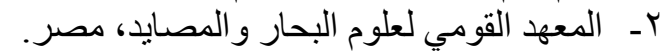

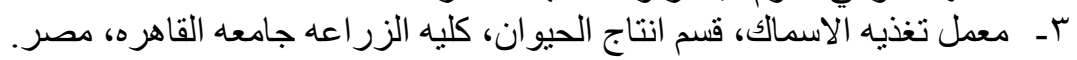

تم دراسه وتقيم امكانيه استخدام نظام البيوفلوك لاستزر الساع سمكه السهليه. اجريت هذه التجربه بمعمل تربيه

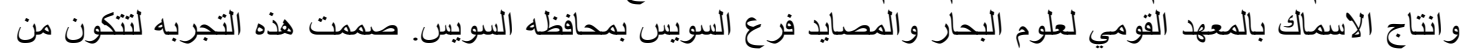

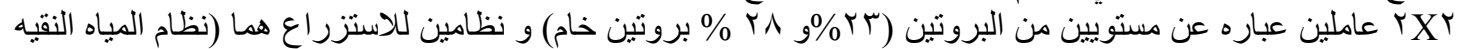

حيث يتم تغيير المياه ونظام البيوفلوك حيث حنيث لايتم تغيير المياه): (CWS

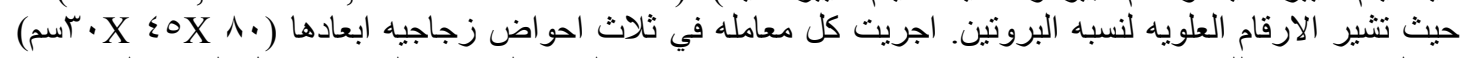

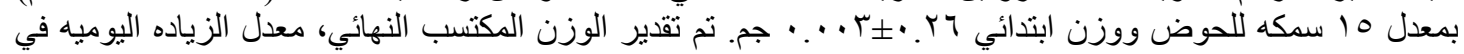

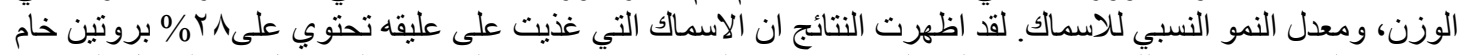

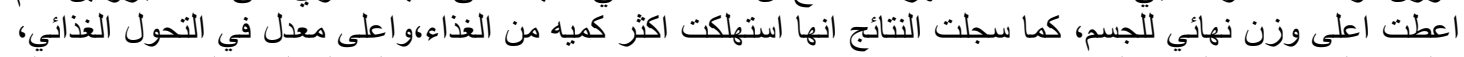

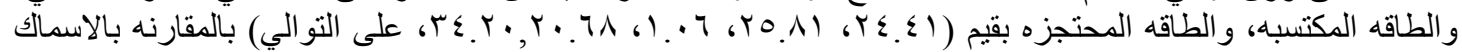

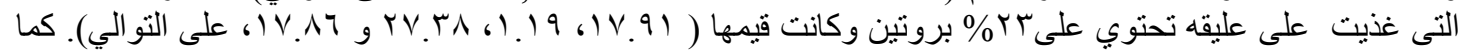

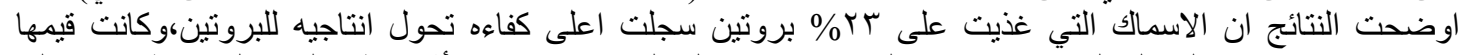

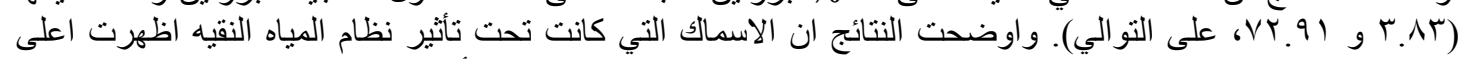

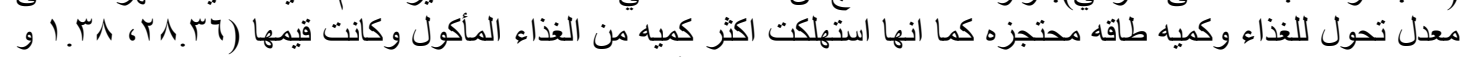

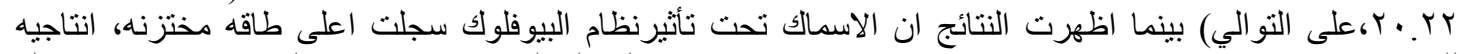

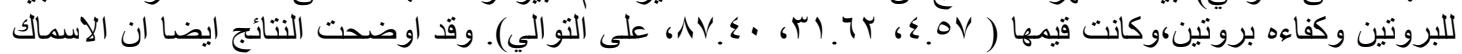

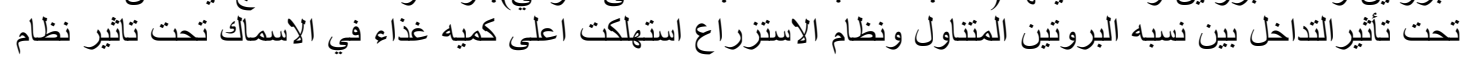

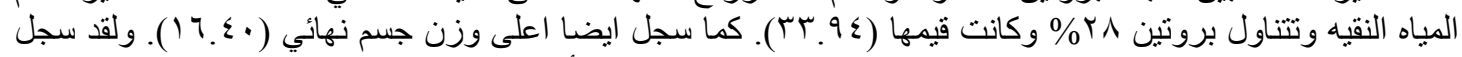

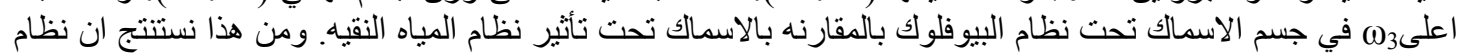
البيوفلوك مناسب لاستزر اع سمكه السهليه اقتصادياً وبيئياً.
} 